\title{
How are universities responding to demands for improved learning environments?
}

\author{
Iyad Abualrub and Bjørn Stensaker, Department of Education, University of Oslo
}

Universities globally are currently facing increased external demands to strengthen and develop their learning environments. The article examines how a sample of Norwegian universities responds to governmental demands concerning establishing good learning environments. Based on document analysis and interviews, the article demonstrates that the concept of learning environments seems to be interpreted and implemented in a standardized way and that institutional work in this area might suffer from a decoupling between "administrative" and "academic" responsibilities. Furthermore, the analysis shows that the universities studied to a great extent seem to rely on copying and imitating understandings of the concept instead of using it to develop more specific and uniquely local practices. In conclusion, the article calls for more attention to the consequences of specific organizational solutions, and it is argued that more attention should be given to identifying factors that enables or constrains how universities handle external pressure for change.

Keywords: university; learning environment; adaptation; higher education; Norway.

\section{Introduction}

The learning environment is an interesting concept to investigate, especially in the changing context of higher education. The concept has recently gained increased attention among educational researchers and policy makers. It has been seen as a significant instrument for facing quality challenges in higher education, especially related to the massification, internationalization and globalization of higher education. Higher education institutions (HEIs) have been faced with the question of how to provide good quality education to an increased number of diverse students and what to offer their students to support the achievement of good learning outcomes (Schuetze and Slowey 2000; Liefner 2003; Author II and Co-author 2013). The emphasis on this question has increased with the internationalization and globalization of higher education and the rise of notions such as knowledge economy and knowledge society (Findly and Tierney 2010; Brine 2006; Robertson 2005; Marginson and Van der Wende 2006). Here, higher education institutions have been challenged to respond to the global competition that emerged for knowledge resources, including human resources such as students, researchers and experts.

As a consequence, educational policies and reforms in many countries, in addition to key international organizations, have recently been paying increased attention to this concept, pushing higher education institutions to improve their learning environments (see, for example, the act relating universities and university colleges passed by the Norwegian Parliament in 2005 [KD 2005]; the UK quality code for higher education [QAA 2014]; the higher education opportunity act passed by the US Congress in 2008 [U.S. Department of Education 2010], in addition to European Higher Education Area [EHEA 2010]; Sursock et al., 2010 and Smith 2010). However, in a recent review of the research literature written on learning environment in higher education (Author I et al. 2013), it was found that the concept of learning environment was understood in very broad and general terms, and the concept seemed to function as an umbrella for various ideas and components. The review identified three main lenses through which the concept of learning environment has been defined and 
researched. The first lens relate learning environment to pedagogical issues, including how teaching is conducted, and how curricula and study programs are designed and developed. The second lens focuses on the organizational and administrative arrangements needed to support teaching and learning activities, and their associated resources and facilities. The third lens emphasizes the networking opportunities offered to students for establishing and engaging in academic and social arenas. These networking opportunities are often seen as conditioned and driven by the development of advanced technologies in teaching and learning. A key finding of the study was that much of the research has been oriented towards learners' perceptions and often ignored the perspective of the institutions although universities and colleges often are held responsible for providing good learning environments by national authorities.

To fill this knowledge gap, the current article focuses on how institutions respond to external expectations concerning developing and improving their learning environments. Our point of departure is driven by the question whether it is only in the research domain that the concept of the learning environment is treated in an unclear fashion or whether the same also goes for policy and practice? Thus, this article takes a closer look at how universities are responding to governmental demands for improving the learning environment. Based on an empirical analysis of Norwegian governmental policies in the learning environment area, the article investigates how five universities in Norway respond to these demands and what specific initiatives and activities that are launched as a consequence.

Norway is a relevant empirical setting for investigating the interest in learning environment as higher education policies in Norway over the last decade have given increased attention to the concept of learning environment and the idea that higher education institutions should develop learning environments which respond to the global changes and challenges that have been taking place in higher education. These institutional expectations have been underlined in a number of governmental white and green papers in the last fifteen years (KD 2001, 2005, 2009, 2013, 2014, 2015), and have been accompanied by governmental attempts of strengthening the institutional autonomy of higher education institutions in Norway providing them with full responsibility for organizational and financial matters (Author II 2014). However, echoing developments in other European countries (Shattock 2014), increased institutional autonomy has been accompanied by stronger accountability measures i.e., resultbased funding schemes, the development of institutional accreditation, and regulations mandating institutions to develop internal systems for quality assurance (Author II 2014). As a national student survey only have been initiated the last couple of years, the responsibility for collecting data on and analysing issues concerning the learning environment has mainly been an institutional responsibility.

Although the Norwegian case as such is unique, the case is still of relevance to increase our knowledge about how universities are dealing with what we can describe as global challenges with respect to how global competitive capacities of higher education institutions in teaching and learning is developing.

The article is organized in four parts. The next section presents the theoretical framework drawn from a broad institutional perspective, followed by a description of the empirical context, data and methods. In the results section, a brief overview of Norwegian governmental policy initiatives with respect to the learning environment is provided, followed by a more indepth description of how the five universities have responded to the governmental initiatives. The article closes with a discussion on the key findings and unresolved issues. 


\section{An institutional framework for analysing organizational responses}

Based on a literature review of how the concept of the learning environment is described and perceived in higher education research, Author I et al. (2013) found that quite diverse views were held about how this concept was defined and understood. This finding can be interpreted in various ways, suggesting that the research field perhaps is rather fragmented and consisting of different disciplines and perspectives and/or that there is considerable conflict and contestation on this issue among researchers.

Regardless of what has caused the situation, one could still argue that uncertainty about how the concept should be understood in research may propagate into both policy and practice. In a situation characterised by a high level of uncertainty, institutional theory stands out as particularly relevant to use in the analysis. Environmental uncertainty is a point of departure for institutional theory, where such uncertainty is seen as a factor driving change, although the different facets of the theory open up for various organizational responses to a situation with high uncertainty. Below, three alternative, but partly overlapping, explanations are provided based on the various perspectives within institutional theory.

An initial explanation, key to newer versions of institutional theory, is that organizations facing uncertainty and that operate within the same field develop over time similar internal structures, values and norms that create common behaviours among them towards change (Meyer and Rowan 1977). The external environment is perceived as the main determining factor of organisational behaviour. The demands of external forces, including that of the government, are seen to have the main say in how organizations behave towards change (DiMaggio and Powell 1991). The main justification of this view is that organizations' existence and continuity rely on the legitimacy and support provided by the external forces that surround them (Scott 2014). The latter is not least important in countries with a high level of public funding of higher education, as is the case in Norway. Hence, in this perspective, one would expect to see responses from universities that, to a large extent, imitate governmental initiatives. Alternatively, the universities will look for popular international "solutions" to the demands arising from the government Labianca et al. (2001), as these also increase their legitimacy towards the government. In essence, this variant of institutional theory predicts a high level of coherence between governmental initiatives and the plans and activities of the individual university. It would also imply that there would be little difference between the universities in how they respond to the governmental initiatives (Drori et al 2006)

A second explanation, more related to older versions of institutional theory, is that institutionalized ideas are not only coming from the outside, but are also found on the inside of organizations. With respect to universities, this means that institutionalization is developed over time as values and cultures of their members are infused into the organization (Selznick 1957, 1996; Hatch 1993). According to this variant of institutional theory, external change initiatives play a lesser role in the development of the university, and it is the traditions and the historical identity of the individual university that is seen as the most important driver of organizational change (Scott 2014). While it may be difficult to reject external demands in higher education today, a likely alternative is that external governmental initiatives in general would be "re-interpreted" and "translated" into fitting existing ways of doing things, and that existing practices and routines related to the learning environment will be continued and perhaps even strengthened further as a response to the governmental initiatives (Greenwood et 
al 2011). This explanation implies that the universities under study would adopt governmental initiatives in very different ways, very much related to their unique organizational identity and their historical legacy. This also implies that the universities would not respond to the governmental initiatives in a similar way.

However, it is also possible to imagine a combination of the two previous explanations, which forms the basis of the third possible outcome. In the third explanation, it is taken for granted that external demands are very difficult to reject, but that internal values and norms are still important for how external ideas are "filtered" into the organization (Greenwood et al 2011). This explanation agrees that the survival of the university depends on responding to the demands of external forces, especially those providing the university with financial resources. However, the role of organizations' members and their associated values and cultures is seen as important in the implementation of these demands (Greenwood and Hinings 1996; Edelman and Bening 1999). This explanation acknowledges that staff engagement, support and cooperation are important to respond to the demands introduced to them. In essence, this variant of institutional theory is also open for "translation" of external initiatives, but only those elements that "fit" the culture, values and the identity of the university (Scott 2014). Hence, this means that responses are highly selective, and that some elements of the governmental initiatives will be picked up while others may be ignored. The result may be that university responses may bear some similarity in some areas, while they differ a lot in others.

As indicated, these three explanations are given as stylized models and should not be seen as mutually exclusive. However, we will argue that they are still very relevant to use as heuristic tools for the empirical investigation since they provide us with different expectations with respect to the comparative analysis.

\section{Data, methods and empirical setting}

The current study can be seen as a comparative case study of how five Norwegian universities (The University of Oslo [UiO], the University of Bergen [UiB], the Norwegian University of Science and Technology [NTNU], the University of Troms $\varnothing$ - The Arctic University of Norway [UiT], and the Norwegian University of Life Sciences [NMBU]) respond to governmental policies concerning enhancing the learning environment in higher education, over the last decade. The study is mainly based on analysis of relevant documents issued by these institutions, in addition to governmental and national documents, including green and white papers. To identify these documents, a search has been made in the archives of the Ministry of Education and Research, NOKUT- the Norwegian Quality Assurance Agency, Universell - the National Coordinator of Accessibility of Higher Education in Norway, and on the webpages of the selected universities.

As the focus of the study is on the concept of "learning environment", this term was the keyword of the search both for policy documents at the national level, and strategic documents at institutional level. However, during our search, we found that the documents that are addressing learning environment issues use various terms in addition to "learning environment", including "study environment", academic environment", and higher education environment". These terms were, therefore, added as search keywords. The documents found have then been filtered by focusing on recommendations, reports, laws and evaluation 
documents. This is for national documents. For the institutional documents, the focus was mainly on the plans and strategic documents issued by the investigated universities, in addition to the web pages of their institutional learning environment committees.

The next step was to (1) explore in the national documents how the concept of learning environment has been approached and what demands have been introduced in relation to it, and (2) examine in the investigated universities' documents how they interpreted this concept and what responses they have developed towards the governmental demands in relation to it. Here, thematic analysis was displayed to explore the significance and place learning environment issues were given in the documents, and how the concepts were interpreted. The analysis started by identifying the main themes related to the notion of learning environment within each document. The documents were further examined by identifying which aspects of learning environment that were afforded significance, and the stated reasons why these aspects were considered important.

In the thematic analysis, and also in the interviews undertaken, links to the theoretical framework was made by taking into account the broader context in which the issue of learning environments were discussed. The interviews were conducted with 35 informants, with an average of 5 informants per university. The informants were identified based on their degree of involvement in developing their institutions' policies concerning the concept of learning environment. The interviews were individual and semi structured, and were conducted during the period of January - October 2013. The main focus of the interviews was (1) why the informants have included learning environments in their institutions' policies and plans, (2) how they understand the notion of learning environment, and (3) which aspects of learning environments they consider to be most significant for their institutions, and why.

Hence, in the analysis indications of imitation and emulation was seen as more likely if documents refer to specific external models or initiatives. Furthermore, if issues of learning environment were linked to historical characteristics of the universities, this was interpreted as sign of paying more attention to the institutional identity and traditions.

\section{Empirical setting}

The five institutions investigated in this study were selected both to cover the institutional diversity of the university landscape in Norway, and to match the assumptions outlined in the theoretical framework. Hence, the five selected universities must be said to be very different with respect to age, geographical location, size, and academic profile (broad research intensive vs more specialized academic profiles).

$\mathrm{UiO}, \mathrm{UiB}$ and UiT, which were respectively founded in 1811, 1946 and 1968, were established as universities and have offered studies in a wide range of disciplines since their establishment. While $\mathrm{UiO}$ and $\mathrm{UiB}$ were founded as discipline-oriented institutions, and as "classic" or "traditional" versions of the Humboldtian university ideal (Paradeise et al 2009) for UiT, a keyword in its foundation was to develop a "different", "modern" and a more "innovative" university (Author II 2006). This meant introducing study programs in interdisciplinary departments and creating a more democratic internal governance system. NMBU was first founded as an agricultural college in 1859. Then, in 1897, it developed into a university college and, later, was granted university status in 2005. NTNU was founded in 1996 as a merger between several higher education institutions. The university has a strong 
technological profile due to the fact that a dominant part of the university was originating from the Norwegian Technical College (NTH) founded in 1910 (Author II 2006).

\section{Results}

\section{Norwegian policy initiatives in the learning environment area}

Over the last decade, higher education policies in Norway have given increased attention to the concept of learning environment and the concept that higher education institutions should develop learning environments which respond to the global changes and challenges that have been taking place in higher education. This interest can be identified in (1) a number of governmental documents issued on higher education the last fifteen years (KD 2001, 2005, $2009,2013,2014,2015)$; (2) in the act relating to universities and university colleges passed by the Norwegian parliament in 2005 (KD 2005); (3) the quality criteria adopted by the Norwegian Agency for Quality Assurance (NOKUT), as shown in its audits of higher education institutions' quality systems issued in 2006, 2010, 2014a, 2014b, 2014c; and (4) the guidelines regarding learning environment introduced by the National Coordinator of Accessibility of Higher Education in Norway (Universell) in 2008 and in a survey conducted on learning environments in HEIs (Universell 2012).

Two of these documents form milestone references compared to the others: the recommendations by the Ministry of Education and Research (KD 2001) and the act relating to universities and university colleges passed by the Norwegian parliament in 2005 (KD 2005). What is emphasized in these two documents regarding learning environments has been echoed and reflected in the other documents mentioned.

In KD (2001), a strong emphasis was put on learning environment as a main element in enhancing the quality of higher education. Learning environments were seen as an important instrument for addressing global changes in higher education and for responding to quality challenges and the increased competition institutions were expected to face. The main justifications given for prioritizing learning environments as such are that it forms a significant tool for improving students' learning outcomes and attracting new students, decreasing the number of dropout students, and increasing the global competiveness of HEIs.

The document also stresses specific conditions that higher education institutions should meet in order to create a learning environment in line with the expectations above. The conditions are introduced through what the document calls a "holistic" picture of a learning environment which consists of physical, socio-psychological and educational environments. Specific issues mentioned include a continuous development of integrative teaching methods and sociocultural and study networking opportunities in addition to welfare services and learning spaces and facilities that can equally engage a larger and more diverse community of learners with different learning cultures and various needs and social and study interests. This is in addition to improving the infrastructures of campuses and buildings including the facilities for students with special needs, employing advanced technologies in teaching and learning, and developing educational programs and curricula that address the market orientations and the needs in job market (KD 2001).

In order achieve these conditions, the document recommends that HEIs should put a stronger focus on (1) developing academic leadership within HEIs, (2) increasing in the size and 
quality of administrative and student advising teams, (3) advancing teachers' skills to teach a more diverse number of students and employ advanced educational technologies, in addition to enhancing the cooperation with student bodies.

The Ministry also required each institution to establish, together with its students, an advisory committee for the learning environment (LMC):
'At the institution there shall be a learning environment committee (...). The committee shall take part in the planning of measures relating to the learning environment and closely follow developments in matters concerning the safety and welfare of the students. The board may also assign other duties to the committee. The learning environment committee shall be kept informed of complaints concerning the learning environment that the institution receives from students. The learning environment committee may submit opinions concerning such matters. The learning environment committee shall be informed of instructions and other individual decisions issued by the Norwegian Labour Inspection Authority. The learning environment committee reports directly to the board and shall submit a report each year concerning the institution's work on the learning environment. The students and the institution shall each have an equal number of representatives on the committee. The committee shall elect a chairman each year alternately from among the institution's and the students' representatives.' (KD 2005, 14)

Given the quite broad understanding of learning environment the Ministry advocated for throughout various documents and statements, the formal LMC still seems to have been given a more focused role in "the safety and welfare" of students, downplaying the academic and pedagogical content of programs and educational provisions. Hence, the LMC could be interpreted to have a special responsibility of physical and infrastructural conditions surrounding the learning experience.

The stress on the these issues was partly based on the Norwegian student organizations' demands that students should be provided with the same good work conditions and welfare services as teachers and other HEI employees receive that help them in their "job" as students. The student organizations demanded that since HEIs have to provide employees with good work conditions and welfare services, this should also be applied to students.

These two policy initiatives, the comprehensive strategic understanding of a learning environment (in the recommendations given in KD 2001) and the more focused understanding (in the 2005 act, KD 2005), have later been reflected in other policy initiatives and documents. In KD (2009), the learning environment was again highlighted, only now to be linked to emerging technologies and the use of ICT. In KD $(2009,2013,2014,2015)$ and Universell $(2008,2012)$, other components further underlined the holistic understanding of the learning environment. In addition to advancing teaching methods, these initiatives require HEIs to continuously develop student welfare, students' socio-cultural networks and services, student counselling services, and curriculums and programs that address the emerging needs in society. Furthermore, NOKUT - the national quality assurance agency - (2006, 2010, 2014a, 2014b, and 2014c) has stressed the importance of learning environments in their audits and evaluations, especially how students perceive this concept and that they have to be put in the centre of HEIs activities in this area. 
To sum up, it seems that governmental policy initiatives concerning learning environments have been advocating a quite broad understanding of the concept without a specific definition given or a consistent understanding of what elements a learning environment should include. Given this broad understanding, it is somewhat surprising that the Ministry only mandated universities and colleges to develop a committee (LMC) that had a far more limited role and responsibility.

\section{Institutional strategies and initiatives in the learning environment area}

How, then, has our sample of universities responded to these policies? This section shows how the investigated universities have interpreted the concept of the learning environment in addition to the responses that the universities have developed towards the governmental demands introduced in relation to it this concept. The section specifically focuses on (1) the roles and responsibilities of the LMC in each university, and (2) how the learning environment concept is reflected in the strategic plans of the selected universities.

In all universities, LMCs have been set up and designed according to the decree specified by the Ministry. All the bodies in all five universities emphasise that their primary task is to provide good psychological and physical environments. More specifically, the LMC are expected to (1) ensure equality in services and treatment to all students, (2) upgrade welfare and health services, (3) develop the buildings and learning places, (4) improve administrative support and flow of information, (5) increase welcoming meetings and activities, (5) provide an inclusive environment that equally engages all students and ensures the quality of eating places and the food they provide, (6) develop libraries and IT facilities, (6) consider the needs of students with special needs, (7) and improve evaluation and complaint systems and the ways in which complaints and evaluation results are followed up (UiO 2015; UiB 2015; NTNU 2015; UiT 2015; NMBU 2015).

In their formal guidelines, LMCs stress that the universities' staff and students should always be reminded and educated with the regulations regarding equality, anti-discrimination and sexual harassments. This is an addition to establishing online systems for complaining; increasing the number of students' consultants, enhancing the dialog and coordination with students; providing online and printed guides for students about their rights, duties, and services provided to students with clearer information about how and where they can get these services; training their administrative staff to provide better support for students; adopting universal design standards for learning places; and allocating funds for developing the available buildings, establishing new ones, and developing IT, technical, and library and laboratory facilities.

However, all the universities investigated have launched numerous initiatives beyond the establishment of LMCs. When exploring the strategic plans and other key documents, there are quite many references to the development of the learning environment of the universities (see for example: UiO 2010, 2011; UiB, 2011, 2012; UiT 2009a, 2009b; NTNU 2011, 2013; NMBU 2010a, 2010b, 2010c, 2012).

When assessing these documents, there are a number of similarities in how the universities formally describe what a 'good learning environment' should look like. Some examples from the strategic plans of the universities illustrate this nicely: 
'The University will offer the nation's best learning environment through clear expectations, closer monitoring, and use of varied teaching methods, learning-enhancing evaluation and good teaching skills.' (UiO 2010, 7).

'...NTNU must take advantage of its unique attributes and develop a clear, ambitious profile for our academic portfolio. Studies must take place in a rich and inclusive learning environment. They must be built on sound research and stimulate critical reflection and innovation.' (NTNU 2011, 16)

'...(the university's) main goal is to provide a learning environment with teaching and assessment methods and academic content that leads to better learning outcomes.' (NMBU $2010,60)$.

'Learning environment-related conditions shall be included in the systematic student evaluations of courses and programmes of study, as well as academic and social environment...The University Library (UB) and Student IT services constitute an important component of the students' learning environment.' (UiT 2009a, 20).

'The University will strengthen as an attractive institution nationally and internationally. For this, it has to develop an active and good learning and study environment. It has to offer internationally recognized research-based education; with high academic quality and emphasis on critical reflection and ethical awareness.' (UiB 2011, 14).

The above quotes show that the universities look at the concept of learning environment similarly through a common lens that focuses on academic and pedagogical settings. For example, many emphasise the pedagogical aspects by highlighting varied teaching methods and good teaching skills (UiO), teaching methods that lead to better learning outcomes (NMBU), and an "active and god learning and study environment" (UiT). Further, the role of assessment and evaluations are highlighted as a means for strengthening learning environments (UiO, NMBU, UiT). Finally, the role of research and critical reflection are seen as important by several actors (NTNU, UiB).

Interviews with managers in the central administration of the universities also indicate quite similar approaches in how political signals were picked up and interpreted at the institutional level:

We have the learning environment committee which is responsible of physical learning environments and the welfare services. You will find such committee in each university in Norway. We formed this committee based on the higher education law made in 2005 ...For the educational and academic issues the responsibility for this part of learning environment is not in the mandate of LMC committee. It is the study committee which responsible of these issues.' (Interview, UiO, January 2013)

'I would say that establishing LMCs is a kind of re-organizing the work on learning environment. Physical and welfare issues put in the hand of the LMUs and the remaining issues including study and teaching, curriculum and courses are left in the hand of the study committee... Before, all were the responsibility of the study committee. Now we made a division of labour, but remember LMC report to the study committee, to the pro-rector of education or study. Who knows maybe in the future 
will be asked to have a pro-rector for physical and welfare environment and a prorector for educational and study environment.' (Interview, UiB, March 2013)

'This concept, I mean learning environment, is like the concept of quality. Maybe you noticed in your study and interviews you had that they can mean and include many things. If you ask me: is this good or not? I think it is good to be open and always improve and update the contents of these concepts. But, what is not good in that or let's say very challenging in it is the organization of the work around all of these contents, and who decides what should be included in these concepts. I mean here that there are different powers or players; you have the students, the academics and the politicians... To meet the interests of all of these powers is the challenge for us as leaders of the institution. You cannot ignore any one of them and you need to learn how to be good compromiser and mediator if you want to be in a central leadership position in a university.' (Interview, UiT, April 2013)

As indicated by the quotes, all of the universities have troubles identifying a precise understanding of the concept of learning environments. All of the universities emphasize the academic and pedagogical content, and while infrastructural, technological and physical factors also are mentioned, they seems very much delegated to the LMCs. Typically, descriptions of learning environments are often linked to words such as being "modern", "inclusive", "international", and "quality", something that was also very visible in the political signals coming from the Ministry of Education. However, while the Ministry of education seems to opt for a very holistic and inclusive understanding of learning environments, it still seems that the requirement to form the special LMC committee have led to a sort of separation between various dimensions that could be included in the concept.

\section{Discussion and conclusions}

In general, the analysis shows that all universities investigated want to provide good learning environments to their students, focusing on developing more inclusive teaching methods and learning conditions, using advanced technology and facilities in teaching and learning, improving and increasing welfare and student support services, and addressing job market needs and market orientations both in their educational programs and curriculums. In this context, internationalization and diversity have been strongly articulated. Creating an international and diverse learning environment that addresses the global developments that have been taking place in higher education were repeatedly highlighted in the strategic plans, institutional initiatives for quality improvement, etc. of all the universities investigated.

It is still interesting to note that there seems to be a divide in how work related to learning environments is taking place within the universities. All of the universities have adapted to the decree about developing LMC that seems to take on a very "administrative" role with the universities and emphasising the legal rights of students, their physical work space, universal access to facilities, and how technology may facilitate these functions. At the same time, there are a number of "academic" initiatives taken in a range of areas emphasising pedagogical and didactical issues with a much stronger link to the study programs and the educational provision. Hence, our first conclusion is that the five universities have decoupled their work on developing learning environments, where issues related to technology development, infrastructure and learning spaces seem to be dealt with quite separately from "academic" development projects. 
However, it is possible to argue that the explanation for such decoupling might be found in the structuring of the higher education sector and in the important role of the Ministry and the quality assurance agency -NOKUT- in the system. As shown in the analysis of the national policy initiatives in the learning environment area, the Ministry had itself a quite broad understanding of the concept, specifying only the establishment of more "administrative" LMCs as a mandatory requirement for the institutions. While it was possible for the institutions to add more tasks to these bodies and have them take on a broader role in the development of the institutional learning environments, none of the universities investigated used their autonomy to launch their own understandings and special profiles in this area.

A feature of this quite standardized way of interpreting learning environments is also that the universities' strategies and plans seems to concentrate on responding to rather generically described "student needs" when developing their learning environments. While this might seem obvious, it can be argued that it is quite interesting that the cultural and institutional features of the universities are not put forward as a way of translating the learning environment concept to local needs, and the ways in which teaching and learning have been conducted within each institution. The plans and strategies of the universities did not mention any internal challenges and problems the universities might experience when attempting to implement the learning environment conditions they specified. Furthermore, none of the universities gave their own definition of what learning environments could imply. Instead, they used quite identical terms and language as the Ministry. If we return to our theoretical framework, it seems that all the institutions imitated both the regulative prescriptions and the normative takes on how learning environments could be interpreted. Hence, our second conclusion is that none of the universities seems to have been able to "translate" or to use their historical legacy and specific institutional characteristics to develop their own take on the learning environment concept.

In a globalized world, concepts such as learning environments are spreading rapidly, often mediated by governmental initiatives, sometimes resulting in ministerial decrees requiring specific institutional actions. In Norway, it can be argued that one such decree, that universities should develop specific LMCs with a special responsibility for the learning environment, seems to have had the paradoxical effect that political ambitions about developing a more holistic approach have led to quite opposite organizational solutions. It can be questioned whether this organizational solution has actually benefitted innovation and creativity with respect to the learning environment. The administrative focus of the LMCs that have been established may well be the reason why it seems difficult for the institutions to develop their own understanding of what a good learning environment might imply and that it seems difficult for the universities in question to link the concept to the academic profile and inherent traditions in the universities. As such, our study shed some interesting lights on what happens when regulatory measures are pushed onto universities, and what happens when universities seemingly adapt to such regulatory requirements without reflecting upon them in a broader way. In a more globalised world where higher education institutions are competing for students, and where offering an attractive learning environment could be seen as a competitive advantage, it can be seen as a paradox that so little thought has gone into how such learning environments can be designed in a more unique fashion.

\section{References}


Author I, Author II, and Co-author 2013. The details of this reference have been removed for purposes of peer review.

Author II 2006. The details of this reference have been removed for purposes of peer review. Author II 2014. The details of this reference have been removed for purposes of peer review.

Author II, and Co-author 2013. The details of this reference have been removed for purposes of peer review.

Brine, J. 2006. "Lifelong Learning and the Knowledge Economy: Those That Know and Those That Do Not: The Discourse of the European Union." British Educational Research Journal 32(5): 649-65.

DiMaggio, P., and W. Powell 1991. The New Institutionalism in Organizational Analysis. Chicago: University of Chicago Press.

Drori, G.S., Meyer, J.W. and Hwang, H. (eds) 2006. Globalizations and Organization: World Society and Organizational Change. Oxford: Oxford University Press.

Edelman, L., and A. Bening 1999. "Incremental Revolution: Organizational Change in Highly Turbulent Environments." Organizational Development Journal 17 (4): 79-94.

EHEA (European Higher Education Area) 2010. "Budapest-Vienna Declaration on the European Higher Education Area." Declaration made by the ministers responsible for higher education in the countries participating in the Bologna Process, met in Budapest and Vienna on March 11 and 12, 2010.

Findly, C., and W. Tierney 2010. Globalisation and Tertiary Education in the Asia-Pacific: The Changing Culture of a Dynamic Market. Singapore: World Scientific.

Greenwood, R., and C. Hinings 1996. "Understanding Radical Organizational Change: Bringing Together the Old and the New Institutionalism." Academy of Management Review 21(4): 1022-1054.

Greenwood, R., Raynard, M., Kodeih, F. and Suddaby, R., 2011. Institutional complexity and organizational responses. The Academy of Management Annals, 5(1), 317-371.

Hatch, M. 1993. "The Dynamics of Organizational Culture" Academy of Management Review, 18 (4): 657-93.

KD (Norwegian Ministry of Education and Research) 2001. Gjфr din plikt - Krev din rett [Do Your Duty-Demand Your Rights]. Oslo: KD. https://www.regjeringen.no/nb/dokumenter/stmeld-nr-27-2000-2001lid194247/?docId=STM200020010027000DDDEPIS\&ch=1\&q=

KD (Norwegian Ministry of Education and Research) 2005. Act Relating to Universities and University Colleges in 2005. Oslo: KD. https://www.regjeringen.no/en/dokumenter/actrelating-to-universities-and-univers/id213307/

KD (Norwegian Ministry of Education and Research) 2009. Lareren Rollen og Utdanningen [The Teacher's Role and the Education]. Oslo: KD. https://www.regjeringen.no/nb/dokumenter/stmeld-nr-11-2008-2009id544920/?docId=STM200820090011000DDDEPIS\&ch=1\&q=L\%C3\%A6reren:\%20 Rollen\%200g\%20utdanningen\&redir=true\&ref=search\&term=L\%C3\%A6reren:\%20Ro llen\%20og\%20utdanningen

KD (Norwegian Ministry of Education and Research) 2013. Tilstandsrapport for Høyere Utdanning [Status Report: Higher Education]. https://www.regjeringen.no/contentassets/319cf97c4e9e4f89b9720baa9aa7f02f/f4284bhele liten.pdf?id=2126317

KD (Norwegian Ministry of Education and Research) 2014. MOOCs for Norway: New Digital Learning Methods in Higher Education. Oslo: KD. https://www.regjeringen.no/contentassets/ff86edace9874505a3381b5daf6848e6/en$\mathrm{gb} / \mathrm{pdfs} /$ nou201420140005000en_pdfs.pdf 
KD (Norwegian Ministry of Education and Research) 2015. Tilstandsrapport for Hoyere Utdanning [Status Report: Higher]. Oslo: KD:

https://www.regjeringen.no/contentassets/1a81fe62f566483295c41a0b9d789010/tilstan dsrapport2015_medforside.pdf

Labianca, G., Fairbank, J.F., Thomas, J.B. and Gioia, D., 2001. Emulation in academia. Balancing Structure and Identity. Organizational Science, 12(3), 312-330.

Liefner, I. 2003. "Funding, Resource Allocation, and Performance in Higher Education Systems." Higher Education 46(4): 469-89.

Meyer, J., and B. Rowan 1977. "Institutionalized Organizations: Formal Structure as Myth and Ceremony." American Journal of Sociology 83(2): 340-363.

NMBU (Norwegian University Life Sciences) 2010a. Strategic Action Plan for Internationalization 2010-2014. Ås: NMBU.

NMBU (Norwegian University Life Sciences) 2010b. Rapport og Planer 2010-2011[Report and Plan 2010-2011]. Ås: NMBU. http://www.umb.no/statisk/okonomi/rapport_og_planer_2010_2011_28.2.pdf

NMBU (Norwegian University Life Sciences) 2010c. Strategy 2010-2013. Ås: NMBU. http://www.umb.no/statisk/om-umb/strategi_umb_2010-13.pdf

NMBU (Norwegian University Life Sciences) 2012. Arsplan 2013 [Plan of Year 2013]. Ås: NMBU. http://www.umb.no/statisk/okonomi/arsplan\%202013.pdf

NMBU (Norwegian University of Life Sciences) 2015. Laeringsmiljøutvalget ved UMB [Learning Environment Committee at UMB]. http://www.nmbu.no/om/utvalg/lmu/laeringsmiljoutvalget

NOKUT (Norwegian Agency for Quality Assurance) 2006. Kriterier for Evaluering av Universiteters og Høgskolers Kvalitetssikringssystem for Utdanningsvirksomheten [Criteria for Evaluation of Universities and Colleges Quality Assurance System for Education Operations]. Oslo: NOKUT.

http://www.nokut.no/Documents/NOKUT/Artikkelbibliotek/Norsk_utdanning/Forskrift er_Kriterier_mm/kriterier_evaluering_revidert_250106.pdf

NOKUT (Norwegian Agency for Quality Assurance) 2010. Evaluering av System Forkvalitetssikring av Utdanningenved Universitetet for Milj $\phi$-ogbiovitenskap [Evaluation of the Quality Assurance System for Education at University of Life Sciences]. Oslo: NOKUT.

http://www.nokut.no/Documents/NOKUT/Artikkelbibliotek/Norsk utdanning/Evalueri ng/Rapporter/2010/UMB_2010.pdf

NOKUT (Norwegian Agency for Quality Assurance) 2014 a. Evaluering av System for Kvalitetssikring av Utdanningen ved NTNU [Evaluation of the Quality Assurance System for Education at NTNU]. Oslo. NOKUT.

http://www.nokut.no/Documents/NOKUT/Artikkelbibliotek/Kunnskapsbasen/Rapporter /Kvalitetssikringsrapporter/2014/NTNU_ks_2014_og_2013.pdf

NOKUT (Norwegian Agency for Quality Assurance) 2014b. Evaluering av System for Kvalitetssikring av Utdanningen ved Universitetet i Oslo [Evaluation of the Quality Assurance System for Education at University of Oslo]. Oslo: NOKUT. http://www.nokut.no/Documents/NOKUT/Artikkelbibliotek/Kunnskapsbasen/Rapporter /Kvalitetssikringsrapporter/2014/UiO_system_kvalitetssikring_2014.pdf

NOKUT (Norwegian Agency for Quality Assurance) 2014c, Evaluering av System for Kvalitetssikring av Utdanningen ved Universitetet i Bergen [Evaluation of the Quality Assurance System for Education at University of Bergen]. Oslo: NOKUT. http://www.nokut.no/Documents/NOKUT/Artikkelbibliotek/Kunnskapsbasen/Rapporter /Kvalitetssikringsrapporter/2014/UiB_system_kvalitetssikring_2014.pdf 
NTNU (Norwegian University of Science and Technology) 2011. Strategi 2011-2020 Kunnskap for Bedre Varden: NTNU-Internasjonalt fremragende [Strategy 2011-2020 Knowledge for Better World: NTNU-International Excellence]. Trondheim: NTNU. http://www.ntnu.no/info/strategi_ntnu_bm.pdf

NTNU (Norwegian University of Science and Technology) 2013. Rapport og Planer 20132014 [Report and plans 2013-2014]. Trondheim: NTNU https://innsida.ntnu.no/documents/10157/1344528730/NTNU+rapport+og+planer+2013 -2014/1a61f22d-1425-4785-9b4e-a7aaa59f19ec

NTNU (Norwegian University of Science and Technology) 2015. Laeringsmiljфutvalget [Learning Environment Committee]. https://www.ntnu.no/adm/utvalg/lmu

OECD (Organisation for Economic Co-operation and Development) 2000. Motivating Students for Lifelong Learning: Education and Skills. Paris: OECD Publishing.

QAA (United Kingdom Quality Assurance Agency for Higher Education) 2014. UK Quality Code for Higher Education. London: QAA. http://www.qaa.ac.uk/assuring-standardsand-quality/the-quality-code

Paradeise, C., Reale, E., Bleiklie, I. \& Ferlie, E., 2009. University Governance. Western Europan Comparative Experiences. Dordrecht: Springer.

Robertson, S. 2005. "Re-Imagining and Re-Scripting the Future of Education: Global Knowledge Economy Discourses and the Challenge to Education Systems.” Comparative Education 41(2): 151-70.

Schuetze, H., and M. Slowy 2002. "Participation and Exclusion: A Comparative Analysis of Non-traditional Students and Lifelong Learners in Higher Education." Higher Education 44(3-4): 309-27.

Scott, W. 2014. Institutions and Organizations. (fourth edition) Thousand Oaks: Sage.

Selznick, P. 1957. Leadership in Administration: A Sociological Interpretation. Evanston: Peterson.

Selznick, P. 1996. "Institutionalism: Old and New." Administrative Science Quarterly 41 (2): 270-77.

Shattock, M. 2014. (ed.) Institutional Governance in Europe. New York: Routledge.

Smith, K. 2010. Assuring Quality in Transnational Higher Education: A Matter of Collaboration or Control?. Studies in Higher Education, 35(7), 793-806.

Sursock, A., Smidt, H., \& Davies, H. (2010). Trends 2010: A Decade of Change in European Higher Education (Vol. 1). Brussels: European University Association.

UiB (University of Bergen) 2011. Strategi 2011-2015 [Strategy 2011-2015]. Bergen: UiB. http://www.uib.no/filearchive/strategi_2011-15_web_1.pdf

UiB (University of Bergen) 2012. Rapport 2012 /Planer 2013 [Report 2012/ Plan 2013]. Bergen: UiB. http://www.uib.no/filearchive/uib_apport2012_planer2013_30april.pdf

UiB (University of Bergen) 2015. Laringsmiljøutvalget [Learning Environment Committee]. http://www.uib.no/ua/48798/1\%C3\%A6ringsmilj\%C3\%B8utvalget

UiO (University of Oslo) 2010. Strategy 2020. Oslo: UiO. http://www.uio.no/english/about/strategy/Strategy2020-English.pdf

UiO (University of Oslo) 2011. Arsplan 2012- 2014 [Years Plan 2012-2014]. Oslo: UiO. http://www.uio.no/om/organisasjon/utvalg/utdanningskomiteen/moter/2012/090212/Utd anningsledelse/\%C3\%85rsplan\%202012-2014_endelig.pdf

UiO (University of Oslo) 2015. Laringsmiljøutvalget [Learning Environment Committee]. http://www.uio.no/om/organisasjon/utvalg/laringsmiljoutvalget/index.html

UiT (University of Troms $\emptyset$-The Arctic University of Norway) 2009a. Quality Assurance System for the Educational Activities at the University Of Troms $\phi$. Troms $\emptyset$ : UiT. 
http://uit.no/Content/213754/Kvalitetssystem\%20for\%20utdanningsvirksomheten $\% 20 \mathrm{E}$ nglish\%20nettversjon\%2030112010.pdf

UiT (University of Troms $\varnothing$-The Arctic University of Norway) 2009b. Strategidokument for Universitetet $i$ Troms $\phi 2009-2013$ [Strategic Document for University of Troms $\varnothing 2009$ 2013]. Troms $\varnothing:$ UiT. http://uit.no/Content/143103/Strategi.pdf

UiT (University of Troms $\varnothing$ - The Arctic University of Norway) 2015. Laringsmiljøutvalget ved UiT Norges arktiske universitet [Learning Environment Committee at the Arctic University of Norway].

http://uit.no/om/enhet/artikkel?p_document_id=69055\&p_dimension_id=88200\&p_me $\underline{\mathrm{nu}=65815}$

U.S. Department of Education 2010. Higher Education Opportunity Act-2008. Washington, DC: U.S. Department of Education.

http://www2.ed.gov/policy/highered/leg/hea08/index.html

Universell (National Coordinator of Accessibility of Higher Education in Norway) 2008.

Universell Utforming av Laringsmilj $\phi$ [Universal Design of Learning Environment].

Trondheim: Universell.

http://www.universell.no/fileshare/fileupload/352/Universell\%20utforming\%20av\%201 \%C3\%A6ringsmilj\%C3\%B8.pdf

Universell (National Coordinator of Accessibility of Higher Education in Norway) 2012, Prosjektrapport: Felles Norsk Laringsmiljфunders $\phi k e l s e$ [Project Report: Joint Norwegian Learning Environment Survey]. Trondheim: Universell.

http://www.universell.no/fileshare/fileupload/501/Sluttrapport_1\%C3\%A6ringsmilj\%C3 \%B8unders\%C3\%B8kelse.pdf 